\title{
Cyanobacteria reduction in the integrated culture of Pacific white shrimp and West India pointed venus in a biofloc system
}

\author{
Lima, P.C.M.; Luna, M.M.S.; Campos, C.V.F.S.; Santos, E.P.; Oliveira, C.Y.B.*; \\ Gálvez, A. O. \& Brito, L. O. \\ Departamento de Pesca e Aquicultura, Universidade Federal Rural de Pernambuco - UFRPE, Dois irmãos, \\ Recife, Pernambuco, 52171-900, Brazil
}

Received August 20, 2020; Accept October 18, 2021

\begin{abstract}
This study aimed to evaluate the integrated culture of the Pacific white shrimp (Litopenaeus vannamei) and the West Indian pointed venus (Anomalocardia flexuosa) reared in a biofloc system. The performance of both species and the phytoplankton community were evaluated. Shrimp monoculture and three stocking densities of West Indian pointed venus (2.5, 5.0 and 7.5 $\mathrm{Kg} \mathrm{m}^{-3}$ ) were evaluated in $0.05 \mathrm{~m}^{3}$ tanks. First of all, the addition of $A$. brasiliana did not affect the water quality parameters of the culture. Regarding the phytoplankton community, 13 taxa were found: 5 cyanobacteria, 4 dinoflagellates, 3 diatoms and 1 green algae. Although diatoms were dominant at the beginning of cultivation, in the middle and at the end a cyanobacterial dominance was observed (proven by ANOSIM and nMDS). The taxa that most contributed to the abundance of cyanobacteria were Aphanocapsa sp. and Pseudanabaena sp. Regarding the performance of the shrimp, all integrated treatments present the higher growth performances (final weight, yield and survival) when compared to shrimp monoculture. Moreover, gradual mortalities of $A$. brasiliana were observed, probably due to the high concentration of cyanobacteria. Thus, it can be observed that the integration of molluscs in shrimp culture can reduce the concentration of harmful algae and improve the zootechnical performance of the shrimp.
\end{abstract}

Keywords: Anomalocardia flexuosa, harmful algae, Integrated Multitrophic Aquaculture, Litopenaeus vanammei, water quality.

\section{INTRODUCTION}

Biofloc systems have been used to reduce the water exchange and consequently to reduce the wastewater production, in addition, it also recycles part of the metabolite waste from fish and shrimp nutrition. This makes the biofloc systems environmentally friendly because they reduce impacts and manage to have greater productivity compared to traditional systems (Crab et al., 2012; Krummenauer et al., 2012).

Biofloc uses an organic carbon source to maintain a satisfactory carbon:nitrogen $(\mathrm{C}: \mathrm{N})$ ratio that favors the growth of heterotrophic, chemoautotrophic and/or nitrifying bacteria. This bacteria community will assimilate the nitrogen compounds in the system, converting it into microbial biomass
(Ebeling et al., 2006; Avnimelech, 2009). Molasses and cane sugar (sucrose) are the most widely used organic carbon sources due to their high availability and low cost, compared to the of organic carbon sources used for bacterial cultures and other heterotrophic and/or mixotrophic microorganisms (Teclu et al., 2009, Lorenzo et al., 2015).

In biofloc systems, there is a naturally organic matter accumulation (Krummenauer et al., 2011), which can favor the growth of other microorganisms harmful to species in cultivation as: Vibrio spp. (Ferreira et al., 2011; Manan et al., 2017) and harmful algae (Brito et al., 2014). To remedy this problem, integrated multi-trophic aquaculture (IMTA) systems have been used to reduce organic waste and also the nitrogen and phosphorus compounds levels. IMTAs have 
been an efficient strategy to minimize the environmental problems associated with the monoculture system (Angel \& Freeman, 2009).

Among the organisms with potential for IMTA are: algae, fish, crustaceans and bivalve molluscs (Troell et al., 2009). Bivalve molluscs are attractive because they reduce the organic matter of the farming systems while the fish can act in phosphorus recovery through its use for skeletal formation (which is absent in crustaceans) (Oliveira \& Brito, 2005; Modesto et al., 2010; Jones et al., 2002).

The residues accumulation in biofloc may influence the phytoplankton community, due to eutrophication (Boyd, 2015), which may result in an increase in microalgal biomass, and a reduction in the diversity of planktonic organisms, with a predominance of harmful algae (Hu et al., 2018), harming the production of the target organism of the culture (Boyd, 2015; Gao et al., 2017).

Many species of harmful algae are potential toxins producers, and for this reason, their abundance raises concerns due to the reduction of oxygen concentrations, in the dark period, and risks to cultivated organisms as well as to their consumers. Cyanobacteria and dinoflagellates are the most harmful algae groups in aquaculture systems; on other hand, diatoms and green algae are the most desired algae groups in aquaculture systems (Sant'Anna \& Azevedo, 2000; Baudin at al., 2006; Van Apeldoorn et al., 2007). The presence of toxic cyanobacteria has already been reported in intensive (Brito et al., 2014; Marinho et al., 2014) and semi-intensive (Barbosa, 2015) shrimp farming.

In this way, the first goal of this study was to evaluate the co-culture of two species of important economic interest, Pacific white shrimp (Litopenaeus vannamei) and West Indian pointed venus (Anomalocardia flexuosa) integrated in a biofloc system. In addition, this study sought to evaluate the ecological influence of $A$. flexuosa at three different densities in the phytoplankton community.

\section{MATERIALS AND METHODS}

\section{Biological material}

L. vannamei post-larvae $(2.73 \pm 0.25 \mathrm{mg})$ were purchased from a commercial laboratory (Aquatec LTDA). A. flexuosa specimens were collected at Mangue Seco beach, Igarassu, Pernambuco, Brazil ( $07^{\circ} 49^{\prime} 44.19^{\prime}$ 'S, $035^{\circ} 50^{\prime} 03.06^{\prime}$ 'W). This work does not require approval from the ethics committee on animal use.

\section{Experimental design and conditions}

The experiment was conducted for 42 days at the Laboratório de Maricultura Sustentável (LAMARSU), which is part of the Departamento de Pesca e Aquicultura at the Universidade Federal Rural de Pernambuco (UFRPE). The experiment was performed in a completely randomized design with four replicates, integrating shrimp (L. vannamei) with a bivalve mollusc (A. flexuosa) reared in a biofloc system.
Five days before the storage of shrimp and molluscs, water from a biofloc matrix tank (total ammonia $0.25 \mathrm{mg} \mathrm{L}^{-1}$, nitrite $1.75 \mathrm{mg} \mathrm{L}^{-1}$, alkalinity $107.00 \mathrm{mg} \mathrm{CaCO}^{3} \mathrm{~L}^{-1}, \mathrm{pH} \mathrm{8.30,30}$ salinity and sedimentable solids $8 \mathrm{~mL} \mathrm{~L}^{-1}$ ), was homogenized and uniformly distributed to fill two tanks.

The experimental units consisted of a $0.05 \mathrm{~m}^{3}$ tank. No water exchange occurred during this time, freshwater was only used to replace water loss due to evaporation. Ammonia control was performed daily by adding molasses as an organic carbon source according to Avnimelech (1999). Moreover, hydrated lime $\left(\mathrm{Ca}(\mathrm{OH})_{2}\right)$ was added in $10 \%$ (by weight) of the daily feed supply, throughout the experimental period, in order to maintain the alkalinity and $\mathrm{pH}$ above $100 \mathrm{mg} \mathrm{L}^{-1}$ and 7.5 , respectively. Three cylindrical porous stones at each experimental unit were used to keep the bioflocs in suspension and maintain oxygen above $5 \mathrm{mg} \mathrm{L}^{-1}$. The luminous intensity was maintained at 2000 lux with a $12 \mathrm{~h}$ photoperiod.

Shrimps were fed with a $40 \%$ crude protein commercial feed (Guabi-Potimirim) four times a day according the Van-Wyk (1999) feed table. In addition, they were reared at a density of 3,000 shrimp $\mathrm{m}^{-3}$. The experiment consisted of four treatments corresponding to a shrimp monoculture (BFT) and three stocking densities of A. flexuosa: 2.5 (BFT 2.5), 5.0 (BFT 5.0) and 7.5 (BFT 7.5) Kg wet weight $\mathrm{m}^{-3}$. The mollusc specimens were washed and sanitized with a sodium hypochlorite bath at $5 \mathrm{~g} \mathrm{~L}^{-1}$ for five minutes, then they were acclimated to the experimental conditions in $0.35 \mathrm{~m}^{3}$ tanks with seawater (30 salinity), at $26{ }^{\circ} \mathrm{C}$ and a density of 3 molluscs $\mathrm{L}^{-1}$. The acclimatization of the molluscs occurred for five days before they were inserted in the experimental units, where $20 \mathrm{~L}$ of water from the biofloc system were added daily.

\section{Water quality}

Dissolved oxygen, salinity, temperature, total dissolved solids and $\mathrm{pH}$ were measured twice a day with a multiparameter probe (YSI model 556, Yellow Springs, Ohio, USA). Total ammonia ( $\left.\mathrm{mg} \mathrm{L}^{-1}\right)$, nitrite $\left(\mathrm{mg} \mathrm{L}^{-1}\right)$ and alkalinity $\left(\mathrm{mg} \mathrm{CaCO}_{3}\right.$ $\mathrm{L}^{-1}$ ) were measured every two days using the colorimetric test (Labcon Test).

\section{Phytoplankton community}

For evaluation of the phytoplankton community, water samples were collected at the beginning, middle (21st day) and end (42th day) of the experiment. To do so, $500 \mathrm{~mL}$ samples of water from each experimental unit were filtered through a cylindrical net with $90 \mu \mathrm{m}$ mesh in order to decrease the suspended solids amount in the sample, then they were filtered with a $50 \mu \mathrm{m}$ mesh to remove the zooplankton, and finally $15 \mu \mathrm{m}$ for phytoplankton collection. The filtered material was immediately fixed in $4 \%$ formalin and stored for further analysis. The identification and quantification of phytoplankton samples were performed using a Sedgewick-Rafter chamber and binocular optical microscope (Olympus, CH30) with a $1.000 \mathrm{x}$ magnification. The organisms were identified based on 
cell morphology at the lowest possible taxonomic level with the aid of specific identification keys (Bicudo \& Menezes, 2006; Wehr et al., 2015). To calculate the abundance, the methodology described by Hötzel \& Croome (1999) was followed. Besides, the groups were categorized according to the relative abundance classification, which they consider in rare $(<10 \%)$, less abundant (10\%-40\%), abundant (40\%-70\%) and dominant (>70\%) (Neumann-Leitão et al., 1995).

\section{Shrimp and mollusc performance}

Shrimp performance was evaluated by weekly biometry. At the end of rearing, survival (\%), final mean weight (g), specific growth rate (SGR), biomass gain $(\mathrm{g})$ and yield $\left(\mathrm{Kg} \mathrm{m}^{-3}\right)$ were measured. Mollusc survival was also evaluated weekly.

\section{Statistical analysis}

All data are presented with mean \pm standard deviation (n $=3$ ). First, the homogeneity of the variances (Cochran) and normality (Shapiro-Wilk) were evaluated. Subsequently, an ANOVA was applied, followed by the Tukey's means comparison test, when necessary, using a level of 0.05 (Zar, 1999). Moreover, cluster analysis (Bray-Curtis similarity) and a non-metric multidimensional scaling (nMDS) were carried out, aiming to observe the similarity of the community in temporal and spatial scale, and their possible group formation; finally, an ANOSIM, with 999 permutations, in order to identify the difference between groups of phytoplankton (Clarke, 1993). PRIMER 6.0 and Assistat 7.6 software's were used.

\section{RESULTS}

\section{Water quality}

Data on water quality variables are shown in Table 1 . There were no significant differences $(p \geq 0.05)$ between water quality parameters, except for alkalinity $(p<0.05)$. During the experiment, the dissolved oxygen and temperature remained close to $5 \mathrm{mg} \mathrm{L}^{-1}$ and $27^{\circ} \mathrm{C}$, respectively. The $\mathrm{pH}$ and alkalinity remained stable near to 8.0 and $120 \mathrm{mg} \mathrm{CaCO}_{3}$ $\mathrm{L}^{-1}$, respectively.

\section{Phytoplankton community}

A total of 13 taxa were identified: 5 cyanobacteria, 3 diatoms, 4 dinoflagellates and 1 green algae, and are listed in Table 2. The richness estimate was 13 for the Chao and Jackknife samplers, thus, the richness estimators reached the asymptote with the observed taxa number. At the beginning of the cultivation, the most representative algae group was diatoms (73.68\%), represented mainly by Thalassiosira spp. In the middle and final of culture, cyanobacteria (ranging from 97.98 to $99.98 \%$ ) were dominant in all treatments, reaching a maximum density of $69,640.5$ cells. $\mathrm{mL}^{-1}$ at the $42^{\text {th }}$ day of culture in the BFT treatment (shrimp monoculture). During that same period diatoms were considered rare, while the dinoflagellates and green algae were rare throughout the experimental period (Figure 1).

In the treatments of integrated culture, the lowest density of cyanobacteria was observed, differing significantly ( $p$ $<0.05$ ) from the BFT treatment, both in the middle and at the end of the experiment. In the middle of culture (21 days), the shrimp monoculture showed from 4.37 to 7.00 times more cyanobacteria than the treatments with A. flexuosa. At the end of culture, this value was $47.69,17.77$ and 113.14 times higher, for BFT 2.5, BFT 5 and BFT 7.5, respectively.

The ANOSIM did not show significant differences in the phytoplankton community among the treatments (Global $R=-0.277$ ), but it showed that in relation to the days of cultivation, phytoplankton showed a significant difference (Global R = 0.944).

There is a $50 \%$ cut, the cluster showed the formation of 2 groups: the group I was composed by day 0 (beginning of the experiment), and the group II was composed by 21 and 42 days - showed a similarity of $61.36 \%$ (Figure 2A). The nMDS analysis confirmed this differentiation of the phytoplankton

Table 1. Water quality parameters in the integrated culture of Pacific white shrimp and West India pointed venus in a biofloc system.

\begin{tabular}{lcccc}
\hline \multirow{2}{*}{ Parameter } & \multicolumn{4}{c}{ Treatments } \\
\cline { 2 - 5 } & $26.47 \pm 0.07^{\mathrm{a}}$ & $26.40 \pm 0.07^{\mathrm{a}}$ & $26.40 \pm 0.08^{\mathrm{a}}$ & $26.45 \pm 0.07^{\mathrm{a}}$ \\
\hline Temperature $\left({ }^{\circ} \mathrm{C}\right)$ & $4.72 \pm 0.05^{\mathrm{a}}$ & $4.78 \pm 0.49^{\mathrm{a}}$ & $4.76 \pm 0.06^{\mathrm{a}}$ & $4.73 \pm 0.05^{\mathrm{a}}$ \\
Dissolved oxygen $\left(\mathrm{mg} \mathrm{L}^{-1}\right)$ & $33.09 \pm 0.46^{\mathrm{a}}$ & $33.20 \pm 0.38^{\mathrm{a}}$ & $34.00 \pm 0.53^{\mathrm{a}}$ & $33.51 \pm 0.46^{\mathrm{a}}$ \\
Salinity & $32.80 \pm 0.41^{\mathrm{a}}$ & $33.04 \pm 0.37^{\mathrm{a}}$ & $33.61 \pm 0.46^{\mathrm{a}}$ & $33.25 \pm 0.42^{\mathrm{a}}$ \\
TDS $\left(\mathrm{g} \mathrm{L}^{-1}\right)$ & $8.14 \pm 0.04^{\mathrm{a}}$ & $8.18 \pm 0.03^{\mathrm{a}}$ & $8.15 \pm 0.04^{\mathrm{a}}$ & $8.17 \pm 0.03^{\mathrm{a}}$ \\
pH & $0.25 \pm 0.03^{\mathrm{a}}$ & $0.44 \pm 0.08^{\mathrm{a}}$ & $0.79 \pm 0.34^{\mathrm{a}}$ & $0.40 \pm 0.14^{\mathrm{a}}$ \\
Ammonia $\left(\mathrm{mg} \mathrm{L}^{-1}\right)$ & $1.96 \pm 0.31^{\mathrm{a}}$ & $2.00 \pm 0.36^{\mathrm{a}}$ & $1.73 \pm 0.35^{\mathrm{a}}$ & $2.62 \pm 0.17^{\mathrm{a}}$ \\
Nitrite $\left(\mathrm{mg} \mathrm{L}^{-1}\right)$ & $133.30 \pm 9.00^{\mathrm{ab}}$ & $115.40 \pm 8.50^{\mathrm{b}}$ & $118.60 \pm 10.11^{\mathrm{ab}}$ & $146.20 \pm 9.71^{\mathrm{a}}$ \\
Alkalinity $\left(\mathrm{mg} \mathrm{L}^{-1}\right)$ &
\end{tabular}

Data presented as mean \pm standard deviation $(n=3)$. Different letters on the same line indicate a significant difference $(\mathrm{p}<0.05)$ using the Tukey test. TDS- Total dissolved solids. 
Table 2. Density (cells $\mathrm{mL}^{-1}$ ) and average relative abundance (\%) of phytoplankton taxa in the integrated culture of Pacific white shrimp and West India pointed venus.

\begin{tabular}{|c|c|c|c|c|c|c|c|c|c|c|}
\hline \multirow{2}{*}{ Taxa } & & \multirow{2}{*}{$\begin{array}{c}\text { Beginning } \\
\text { BFT }\end{array}$} & \multicolumn{4}{|c|}{ Middle (21st day) } & \multicolumn{4}{|c|}{ End (42th day) } \\
\hline & & & BFT 2.5 & BFT 5.0 & BFT 7.5 & $\mathrm{BFT}$ & BFT 2.5 & BFT 5.0 & BFT 7.5 & \\
\hline \multirow{2}{*}{ Diatoms } & $\left(\right.$ cells $\mathrm{mL}^{-1}$ ) & 164.3 & $8^{\mathrm{a}}$ & $14.2^{\mathrm{a}}$ & $22.6^{\mathrm{a}}$ & $2.3^{\mathrm{a}}$ & $0^{\mathrm{a}}$ & $0^{\mathrm{a}}$ & $0^{\text {a }}$ & $0^{\mathrm{a}}$ \\
\hline & $(\%)$ & 73.67 & 0.01 & 0.07 & 0.11 & 0.02 & 0 & 0 & 0 & 0 \\
\hline \multirow{2}{*}{ Thalassiosira sp.1 } & $\left(\right.$ cells $\left.\mathrm{mL}^{-1}\right)$ & 107 & 7 & 11.6 & 18.6 & 2.3 & 0 & 0 & 0 & 0 \\
\hline & $(\%)$ & 46.38 & 0.01 & 0.06 & 0.09 & 0.02 & 0 & 0 & 0 & 0 \\
\hline \multirow{2}{*}{ Thalassiosira sp.2 } & $\left(\right.$ cells $\left.\mathrm{mL}^{-1}\right)$ & 56 & 1 & 2.6 & 4 & 0 & 0 & 0 & 0 & 0 \\
\hline & $(\%)$ & 26.79 & 0 & 0.01 & 0.02 & 0 & 0 & 0 & 0 & 0 \\
\hline \multirow[b]{2}{*}{ Pseudostaurosira $\mathrm{sp}$} & $\left(\right.$ cells $\left.\mathrm{mL}^{-1}\right)$ & 1.3 & 0 & 0 & 0 & 0 & 0 & 0 & 0 & 0 \\
\hline & $(\%)$ & 0.5 & 0 & 0 & 0 & 0 & 0 & 0 & 0 & 0 \\
\hline \multirow{2}{*}{ Cyanobacteria } & $\left(\right.$ cells $\left.\mathrm{mL}^{-1}\right)$ & 48.6 & $56,239.5^{\mathrm{a}}$ & $12,808.7^{\mathrm{b}}$ & $12,013.6^{\mathrm{b}}$ & $8,024.9^{b}$ & $69,491.5^{\mathrm{a}}$ & $1,457.2^{\mathrm{b}}$ & $3,910.4^{\mathrm{b}}$ & $614.2^{c}$ \\
\hline & $(\%)$ & 20.08 & 99.91 & 99.84 & 99.81 & 99.82 & 99.98 & 99.65 & 99.9 & 97.98 \\
\hline \multirow{2}{*}{ Pseudanabaena sp. } & $\left(\right.$ cells $\left.\mathrm{mL}^{-1}\right)$ & 21.3 & 10.3 & 951.3 & 12 & 11.6 & $52,016.6$ & 287 & $1,217.3$ & 188.9 \\
\hline & $(\%)$ & 7.52 & 0.02 & 13.38 & 0.15 & 0.15 & 65.48 & 36.66 & 46.84 & 57.49 \\
\hline \multirow{2}{*}{ Synechococcus sp.1 } & $\left(\right.$ cells $\mathrm{mL}^{-1}$ ) & 24.3 & 0 & 0 & 0 & 0 & 0 & 0 & 0 & 0 \\
\hline & $(\%)$ & 11.75 & 0 & 0 & 0 & 0 & 0 & 0 & 0 & 0 \\
\hline \multirow{2}{*}{ Synechocystis sp.2 } & $\left(\right.$ cells $\left.\mathrm{mL}^{-1}\right)$ & 3 & 0 & 0 & 0 & 0 & 0 & 0 & 0 & 0 \\
\hline & $(\%)$ & 0.81 & 0 & 0 & 0 & 0 & 0 & 0 & 0 & 0 \\
\hline \multirow{2}{*}{ Chroococcus sp. } & $\left(\right.$ cells $\left.\mathrm{mL}^{-1}\right)$ & 0 & 417 & 182.6 & 159 & 67 & 218.3 & 124.3 & 958.6 & 46 \\
\hline & $(\%)$ & 0 & 6.06 & 1.86 & 1.83 & 0.87 & 1.47 & 10.54 & 16.25 & 13.12 \\
\hline \multirow{2}{*}{ Aphanocapsa sp. } & $\left(\right.$ cells $\mathrm{mL}^{-1}$ ) & 0 & $52,052.20$ & $11,674.80$ & 11,843 & $7,946.3$ & $17,256.60$ & $1,045.9$ & $1,734.50$ & 379.3 \\
\hline & $(\%)$ & 0 & 93.83 & 84.6 & 97.83 & 98.8 & 33.03 & 52.45 & 36.81 & 27.37 \\
\hline \multirow{2}{*}{ Dinoflagellates } & $\left(\right.$ cells $\left.\mathrm{mL}^{-1}\right)$ & 11.2 & $33.9^{\mathrm{a}}$ & $17.2^{\mathrm{a}}$ & $7.6^{\mathrm{a}}$ & $13.9^{\mathrm{a}}$ & $6.3^{\mathrm{a}}$ & $3.6^{\mathrm{a}}$ & $3.3^{\mathrm{a}}$ & $2.3^{\mathrm{a}}$ \\
\hline & $(\%)$ & 6.05 & 0.07 & 0.1 & 0.07 & 0.15 & 0.01 & 0.35 & 0.09 & 2.02 \\
\hline \multirow{2}{*}{ Schuetiella mitra } & $\left(\right.$ cells $\mathrm{mL}^{-1}$ ) & 1.3 & 0.3 & 2.3 & 0.3 & 1 & 0 & 0 & 0 & 0 \\
\hline & $(\%)$ & 0.66 & 0 & 0.01 & 0 & 0.01 & 0 & 0 & 0 & 0 \\
\hline \multirow{2}{*}{ Oxyrrhis sp. } & $\left(\right.$ cells $\left.\mathrm{mL}^{-1}\right)$ & 5 & 4.6 & 2.6 & 1.3 & 2.6 & 0.3 & 0 & 0 & 0 \\
\hline & $(\%)$ & 1.83 & 0.01 & 0.02 & 0.02 & 0.03 & 0 & 0 & 0 & 0 \\
\hline \multirow{2}{*}{ Lophodinium sp. } & $\left(\right.$ cells $\mathrm{mL}^{-1}$ ) & 0.6 & 0 & 0 & 0 & 0 & 0 & 0 & 0 & 0 \\
\hline & $(\%)$ & 0.16 & 0 & 0 & 0 & 0 & 0 & 0 & 0 & 0 \\
\hline \multirow{2}{*}{ Coolia sp. } & $\left(\right.$ cells $\left.\mathrm{mL}^{-1}\right)$ & 4.3 & 29 & 12.3 & 6 & 10.3 & 6 & 3.6 & 3.3 & 2.3 \\
\hline & $(\%)$ & 3.4 & 0.06 & 0.07 & 0.05 & 0.11 & 0.01 & 0.35 & 0.09 & 2.02 \\
\hline \multirow{2}{*}{ Green algae } & $\left(\right.$ cells $\mathrm{mL}^{-1}$ ) & $0.3^{\mathrm{a}}$ & $0^{\text {a }}$ & $0^{\text {a }}$ & $0^{\mathrm{a}}$ & $0^{\mathrm{a}}$ & $0^{\text {a }}$ & $0^{\text {a }}$ & $0^{\text {a }}$ & $0^{\mathrm{a}}$ \\
\hline & $(\%)$ & 0.18 & 0 & 0 & 0 & 0 & 0 & 0 & 0 & 0 \\
\hline \multirow{2}{*}{ Diplochloris sp. } & $\left(\right.$ cells $\mathrm{mL}^{-1}$ ) & 0.3 & 0 & 0 & 0 & 0 & 0 & 0 & 0 & 0 \\
\hline & $(\%)$ & 0.18 & 0 & 0 & 0 & 0 & 0 & 0 & 0 & 0 \\
\hline Total & $\left(\right.$ cells $\left.\mathrm{mL}^{-1}\right)$ & 224.4 & 56.281 .4 & 12.840 .1 & 12.043 .8 & 8.041 .1 & 69.646 .8 & 1.460 .8 & 3.913 .7 & 616.3 \\
\hline
\end{tabular}

Data presented as mean \pm standard deviation $(\mathrm{n}=3)$. Different letters on the same line indicate a significant difference $(\mathrm{p}<0.05)$ using the Tukey test.

community, over time, through the distance between the groups formed (Figure 2B).

The SIMPER multivariate analysis showed at beginning, middle and end of the culture, the typified taxa were Thalassiosira sp.1 (36.89\%), Chroococcus sp. (31.09\%) and Chroococcus sp. (45.07\%), respectively. Furthermore, with this analysis it was found that in relation to treatments throughout the experimental period, the 


\section{A}
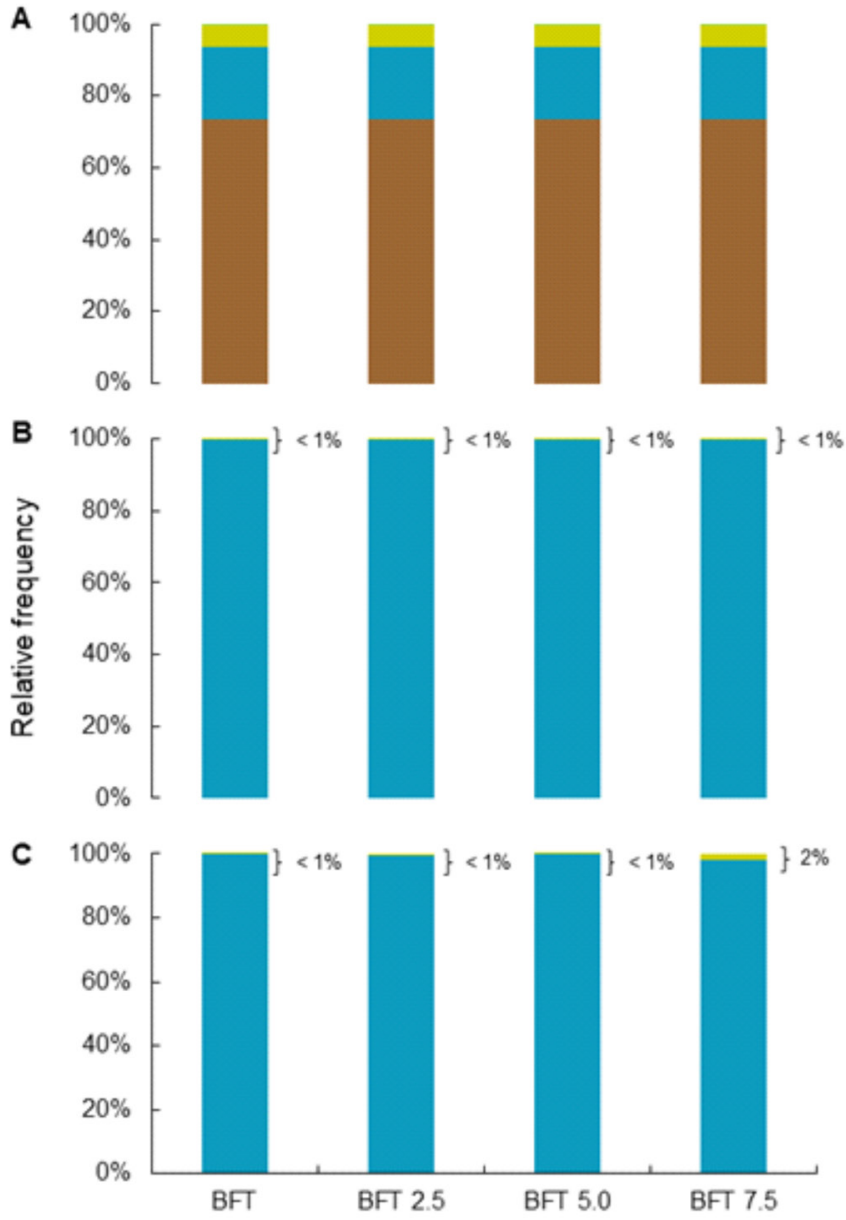

=Diatoms $=$ Cyanobacteria $=$ Dinoflagellates $=$ Green algae

Figure 1. Relative abundance of phytoplankton presents in the Pacific white shrimp and West Indian pointed venus integrated in a biofloc system at 0 (A), 21 (B) and 42 (C) days of cultivation.

taxa Pseudanabaena sp. $(36.03-65.83 \%)$ was the most contributed in all treatments.

\section{Zootechnical performance}

At the end of the 42 days of the culture, was observed that the shrimp performance was similar among the treatments of integrated cultivation A. flexuosa, presented a higher final weight, survival, biomass gain and productivity when compared to monoculture (Table 3). Nevertheless, a high mortality of A. flexuosa in all stocking densities used in the present study (Figure 3).

\section{DISCUSSION}

The water quality variables were kept within the ideal range for the cultivation of the Pacific white shrimp (Samocha et al., 2017). The low nitrogen compounds suggested that ammonia control was mostly driven by heterotrophic pathway (Poli et al., 2019). Temperature and salinity were also according to life environment of West Indian pointed venus (Oliveira et al., 2011) and also culturing systems (Oliveira et al., 2019a).

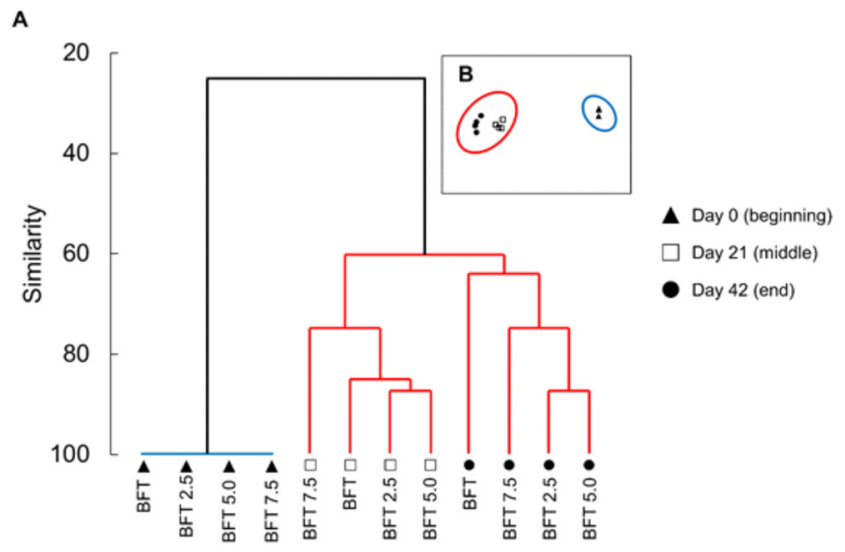

Figure 2. Cluster analysis (A) and non-metric multidimensional scaling (nMDS) (B) of the phytoplankton community present in the Pacific white shrimp and West Indian pointed venus integrated in a biofloc system.

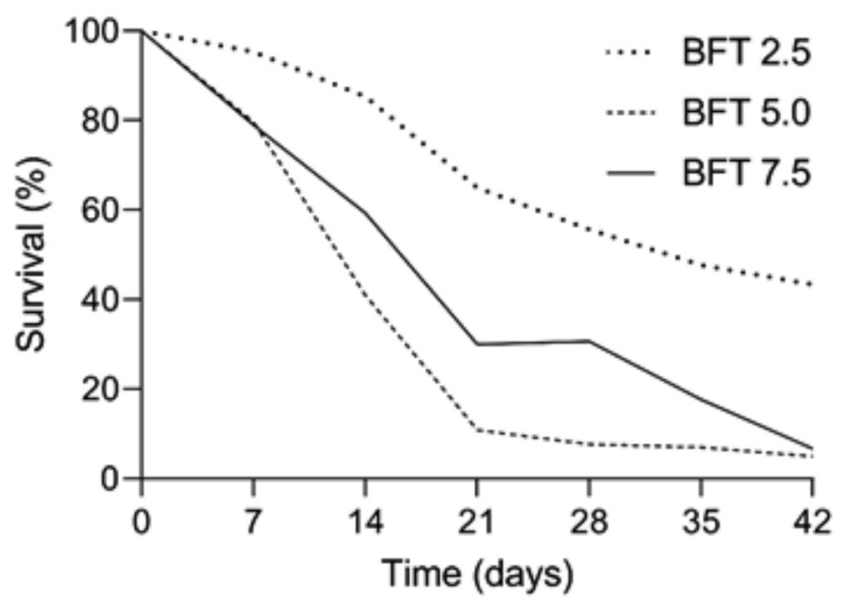

Figure 3. Survival (\%) of West Indian pointed venus integrated with Pacific white shrimp in a biofloc system.

Table 3. Zootechnical performance of Pacific white shrimp in the integrated culture with West India pointed venus in a biofloc system.

\begin{tabular}{lcccc}
\hline \multirow{2}{*}{ Parameter } & \multicolumn{4}{c}{ Treatments } \\
\cline { 2 - 5 } & BFT & BFT 2.5 & BFT 5.0 & BFT 7.5 \\
\hline Weight (g) & $0.15 \pm 0.02^{\mathrm{b}}$ & $0.31 \pm 0.06^{\mathrm{a}}$ & $0.25 \pm 0.01^{\mathrm{a}}$ & $0.27 \pm 0.05^{\mathrm{a}}$ \\
Survival (\%) & $38.56 \pm 3.28^{\mathrm{b}}$ & $58.89 \pm 3.31^{\mathrm{a}}$ & $61.33 \pm 1.15^{\mathrm{a}}$ & $62.56 \pm 4.13^{\mathrm{a}}$ \\
Biomass gain (g) & $8.63 \pm 1.31^{\mathrm{b}}$ & $25.08 \pm 3.6^{\mathrm{a}}$ & $21.31 \pm 1.21^{\mathrm{ab}}$ & $24.61 \pm 5.50^{\mathrm{a}}$ \\
$\begin{array}{l}\text { Productivity } \\
\text { Kg m }\end{array}$ & $\left.0.17 \pm 0.03^{\mathrm{b}}\right)$ & $0.50 \pm 0.07^{\mathrm{a}}$ & $0.43 \pm 0.02^{\mathrm{ab}}$ & $0.49 \pm 0.11^{\mathrm{a}}$ \\
SGR & $6.79 \pm 0.27^{\mathrm{a}}$ & $8.07 \pm 0.43^{\mathrm{a}}$ & $7.68 \pm 0.08^{\mathrm{a}}$ & $7.82 \pm 0.39^{\mathrm{a}}$ \\
\hline
\end{tabular}

Data presented as mean \pm standard deviation $(n=3)$. Different letters on the same line indicate a significant difference $(\mathrm{p}<0.05)$ using the Tukey test. SGR - specific growth rate.

From the third week of the cultivation on, a change in the culture watercolor was observed (typically brown color traditional biofloc systems, to a blue-green color), which motivated us to examine the phytoplankton community. 
Diatoms were more abundant at the beginning of cultivation in all treatments, but over time there was a reduction in this abundance that may be linked to the gradual eutrophication of the system water, caused by the feeding rates and accumulation of organic matter that can favor groups of algae more resistant, such as cyanobacteria. Cyanobacteria have several biochemical, physiological, genetic and reproductive adaptations for the formation of blooms in adverse conditions (e.g., low light, production of info-chemicals, tolerance to high levels of nitrogenous and phosphorus compounds etc.) (Reichwaldt \& Ghadouani, 2012; Yusoff et al., 2010). Although dinoflagellates were not representative for this study, they are also known to have large impacts on aquaculture, such as the recent Godzilla Red Tide event in Chile, the largest fish farm mortality, equivalent to an export loss of USD $\$ 800$ million which when combined with shellfish toxicity, resulted in a major social-economic imbalance (Mardones, 2020; Trainer et al., 2020). According to Yusoff et al. (2010), a diatom density reduction $\left(9.19 \times 10^{3}\right.$ to $3.07 \times 10^{3}$ cells $\left.\mathrm{mL}^{-1}\right)$ was observed in a cyanobacterial bloom $\left(7.20 \times 10^{3}\right.$ to $122.37 \times 10^{3}$ cells $\left.\mathrm{mL}^{-1}\right)$ during the shrimp farming in a eutrophic water.

In biofloc systems, there is a low transparency of the water, due to microbial flocs, and an increase in phosphorus compounds throughout culture mainly due to the decomposition of the uneaten feed and the excretion of the cultivated organisms. These facts are already exhaustively known for causing harmful cyanobacterial blooms (Oliveira et al., 2019b) and they are the most likely causes for the dominance of cyanobacteria in the present study. Moreover, although there has been no negative impact on water quality parameters, it is also likely that low survival rates are due to toxin production (Kangur et al., 2005; Malbrouck \& Kestemont, 2006).

The most abundant cyanobacteria taxa found in this study, are potential toxin producers: Aphanocapsa genus is potential producers of microcystins. Cyanobacterial dominance already also reported in a number of studies (Brito et al., 2014; Wei et al., 2016; Marinho et al., 2017). According to Brito et al. (2014) and Marinho et al. (2017) a low nitrogen: phosphorus ratio can favor the cyanobacteria in aquaculture systems. This is because some cyanobacteria genera can to fix atmospheric nitrogen $\left(\mathrm{N}_{2}\right)$ when in low concentrations in water. Whereas the bacterial community is well established in biofloc systems and it has a faster growth rate than algae and cyanobacteria (an order of magnitude), the atmospheric nitrogen assimilation is the best reason for the dominance of cyanobacteria in biofloc systems. Environmental factors such as light availability, temperature, dissolved inorganic compounds concentrations can result in a succession of dominant phytoplankton species (Casé et al., 2008; Oliveira et al., 2020) and this can explain the difference in dominance groups at the beginning, middle and end of culture.

The highest shrimp zootechnical performance was found in integrated cultivations (BFT 2.5, BFT 5.0 and BFT 7.5) when compared to shrimp monoculture. It is likely that the increase in shrimp zootechnical performance was due to reducing the concentration of cyanobacteria cells by molluscs. This fact also justifies the low survival of molluses that were probably infected by toxins (Queiroga et al., 2017). Therefore, it is possible to affirm the following cascade effect: (i) West Indian pointed venus reduced the cyanobacterial load, which resulted in a (ii) highest zootechnical performance for shrimp in the integrated cultures. (iii) On the other hand, West Indian pointed venus specimens were probably intoxicated by cyanobacterial toxins. Molluscs, being filter organisms, can retain suspended particles in water and can function as a biological filter (Oliveira \& Oliveira, 2019). This filtration can affect the amount of material present in the water column (Deslous-Paoli et al., 1992), as happened with cyanobacteria.

Although the integrated shrimp and mollusc cultures have shown better zootechnical performance when compared to shrimp monoculture, other studies have already reported higher final weight $(0.68-1.08 \mathrm{~g})$, productivity $(1.21-2.46$ $\mathrm{Kg} \mathrm{m}^{-3}$ ) and survival (71.3 - 95.6\%) for Pacific white shrimp monoculture in biofloc systems. Moreover, a survival of West Indian pointed venus post-larvae of $53.24 \%$ was reported by Oliveira et al. (2019a) in a super-intensive culture under a recirculation aquaculture system. In addition to the higher concentration of cyanobacteria, shear forces and the high content of organic matter in biofloc systems may also have negatively influenced mollusc mortality (Rodrigues, 2009). Therefore, it is still necessary to investigate a better way to dispose of molluscs in IMTA using biofloc, towards a reduce stress factors to these organisms.

\section{CONCLUSIONS}

In summary, the concentration of cyanobacteria, especially the genera Aphanocapsa sp. and Pseudanabaena sp., negatively affected the zootechnical performance of shrimp and molluses cultured integrated in a BFT system. However, the integrated cultures showed advantages in the shrimp zootechnical performance and presented a lower concentration of cyanobacteria - due to the filtration by the molluscs. Finally, West Indian pointed venus showed low survival in biofloc system regardless of stocking density.

\section{ACKNOWLEDGMENTS}

This research was supported by Conselho Nacional de Desenvolvimento Científico e Tecnológico (CNPq) and Coordenação de Aperfeiçoamento de Pessoal de Nível Superior (CAPES) - Finance Code 001.

\section{REFERENCES}

ANGEL, D. \& FREEMAN, S. 2009. Integrated aquaculture (INTAQ) as a tool for an ecosystem approach to the marine farming sector in the Mediterranean Sea. In: SOTO, D. Integrated mariculture: a global review.

FAO. 2018. Fisheries and Aquaculture Technical Paper, Rome. p. 
$133-183$.

AVNIMELECH, Y. 2009. Biofloc Technology: A Pratical Guide Book. $2^{\circ}$ ed. Baton Rouge: The world Aquaculture Society. 182p.

BARAK, Y., CYTRYN, E., GELFAND, I., KROM, M. \& VAN RIJN, J. 2003. Phosphorus removal in a prototype, recirculating aquaculture system. Aquaculture 220(1-4): 313-326. https://doi. org/10.1016/S0044-8486(02)00342-3

BICUDO, C.E.M. \& MENEZES, M. 2006. Gêneros de algas de águas continentais do Brasil (chave para identificação e descrições). $2^{\circ}$ ed. São Carlos: RiMa. 502p.

BRITO, L.O., VINATEA, L.A., SOARES, R.B., SEVERI, W., MIRANDA, R.H., SILVA, S.M.B.C., COIMBRA, M.R. \& GALVEZ, A.O. (2014). Water quality, phytoplankton composition and growth of Litopenaeus vannamei (Boone) in an integrated biofloc system with Gracilaria birdiae (Greville) and Gracilaria domingensis (Kützing). Aquac. Int. 22(5): 16491664. https://doi.org/10.1007/s10499-014-9771-9

BRITO, C., VALLE, B., INTERAMINENSE, J., PEIXOTO, S., LIMA-FILHO, J. V. \& SOARES, R. 2016. Microbiological quality of Litopenaeus vannamei culture using conventional and biofloc systems. Aquac. Res. 47(10): 3098-3108. https://doi. org/10.1111/are. 12760

CASÉ, M., LEÇA, E.E., LEITÃO, S.N., SANT'ANNA, E.E., SCHWAMBORN, R. \& MORAES JÚNIOR, A.T. 2008. Plankton community as an indicator of water quality in tropical shrimp culture ponds. Mar Pollut. Bull. 56(7): 1342-1352. https:// doi.org/10.1016/j.marpolbul.2008.02.008

CHAMORRO-LEGARDA, E., MENDES, L.G., BEZERRA, G.G.O., ESPÍRITO SANTO, C.M., SEIFFERT, W.Q. \& VIEIRA, F.N. 2016. Açúcar refinado como fonte de carbono no berçário de camarões cultivados em sistema de bioflocos. Bol. Inst. Pesca 42(2): 443-448.

CLARKE, K.R. 1993. Non-parametric multivariate analyses of changes in community structure. Austral. J. Ecol. 18(1): 117143. https://doi.org/10.1111/j.1442-9993.1993.tb00438.x

CRAB, R., DEFOIRDT, T., BOSSIER, P. \& VERSTRAETE, W. 2012. Biofloc technology in aquaculture: Beneficial effects and future challenges. Aquaculture 356: 351-356. https://doi. org/10.1016/j.aquaculture.2012.04.046

EBELING, J.M., TIMMONS, M.B. \& BISOGNI, J.J. 2006. Engineering analysis of the stoichiometry of photoautotrophic, autotrophic, and heterotrophic removal of ammonia-nitrogen in aquaculture systems. Aquaculture 257: 346-358. https://doi. org/10.1016/j.aquaculture.2006.03.019

FERREIRA, N.C., BONETTI, C. \& SEIFFERT, W.Q. 2011. Hydrological and water quality indices as management tools in marine shrimp culture. Aquaculture 318(3-4): 425-433. https:// doi.org/10.1016/j.aquaculture.2011.05.045

GÁLVEZ, A.O., CAMPOS, C.V.F.S., SANTOS, I.G.S., MARINHO, Y.F., VINATEA, L. \& BRITO, L.O. 2015. Plankton communities in shrimp monoculture, integrated biofloc system. Available in: $\quad<$ https://www.aquaculturealliance.org/advocate/planktoncommunities-in-shrimp-monoculture-integrated-bioflocsystem/> Accessed on: Jan 24. 2018.

HÖTZEL, G. \& CROOME, R. A. 1999. Phytoplankton methods manual for Australian Freshwaters. Available in: < http:// phytobioimaging.unisalento.it/Portals/7/Documents/General Documentation/A\%20Phytoplankton\%20Manual\% 20 methods\%20Australia.pdf $>$. Accessed in: Jan 252018.

JONES, A.B., PRESTON, N.P. \& DENNISON, W.C. 2002. The efficiency and condition of oyster and macroalgae used as biological filters of shrimp pond effluent. Aquac. Res. 33(1): 1-19. https://doi.org/10.1046/j.1355-557X.2001.00637.x

KRUMMENAUER, D., PEIXOTO, S., CAVALLI, R. O.,
POERSCH, L. H. \& WASIELESKY JÚNIOR, W. 2011. Superintensive culture of white shrimp, Litopenaeus vannamei, in a biofloc technology system in Southern Brazil at different stocking densities. J. World Aquac. Soc. 42(5): 726-733. https:// doi.org/10.1111/j.1749-7345.2011.00507.x

KRUMMENAUER, D., SEIFERT JR. C. A., POERSCH, L. H., FOES, G. K., LARA, G. R. \& WASIELESKY JÚNIOR, W. 2012. Cultivo de camarões marinhos em sistema de bioflocos: análise de reutilização da água. Atlântica 34(2): 103-111.

LORENZO, M.A., SCHVEITZER, R., ESPIRITO SANTO, C.M., CANDIA, E.W.S., MOURIÑO, J.L.P., LEGARDA, E.C., SEIFFERT, W.Q. \& VIEIRA, F.N. 2015. Intensive hatchery performance of the Pacific white shrimp in biofloc system. Aquac. Eng. 67: 53-58. https://doi.org/10.1016/j.aquaeng.2015.05.007

MANAN, H., MOH, J.H.Z., KASAN, N.A., SURATMAN, S. \& IKHWANUDDIN, M. 2017. Identification of biofloc microscopic composition as the natural bioremediation in zero water exchange of Pacific white shrimp, Penaeus vannamei, culture in closed hatchery system. Appl. Water Sci. 7: 24372446. https://doi.org/10.1007/s13201-016-0421-4

MARINHO Y.F., BRITO L.O., SILVA C.V.F., SANTOS I.G.S. \& GALVEZ A.O. 2014. Effect of addition of Navicula sp. on plankton composition and post larvae growth of Litopenaeus vannamei reared in culture tanks with zero water exchange. Lat. Am. J. Aquat. Res. 42: 427-437. https://doi.org/ 103856/vol42issue 3-fulltext-4

MARINHO Y.F., BRITO L.O., SILVA C.V.F., SEVERI, W., ANDRADE, H.A. \& GALVEZ, A.O. 2017. Effect of the addition of Chaetoceros calcitrans, Navicula sp. and Phaeodactylum tricornutum (diatoms) on phytoplankton composition and growth of Litopenaeus vannamei (Boone) postlarvae reared in a biofloco system. Aquac. Res. 48: 4155-4164. https://doi.org/10.1111/ are. 13235

MODESTO, G.A., MAIA, E.P., OLIVEIRA, A. \& BRITO, L.O. 2010. Utilização de Crassostrea rhizophorae (Guilding 1828) no tratamento dos efluentes do cultivo de Litopenaeus vannamei (Boone 1931). Pan-Am. J. Aquat. Sci. 5(3): 367-375.

NEUMANN-LEITÃO, S., GUSMÃO, L.M.O., VIEIRA, D.A.N. \& PARANHOS, J.D.N. 1995. Zooplâncton da área estuarina do Rio Formoso - PE (BRASIL). Trop. Oceanogr. 23: 55-64.

OLIVEIRA, A. \& BRITO, L.O. 2005. Treating shrimp farming effluent using the native oyster, Crassostrea rhizophorae, in Brazil. World Aquac. 36(3): 60 - 63.

OLIVEIRA, I., AMORIM, A., LAVANDER, H., PEIXOTO, S. \& GÁLVEZ, A.O. 2011. Spatial and temporal distribution of the shellfish Anomalocardia brasiliana (Gmelin, 1791) on Mangue Seco beach, Pernambuco, Brazil. Int. J. Aquat. Sci. 2(1): 68-79.

OLIVEIRA, C.D.L. \& OLIVEIRA, C.Y.B. 2019. Growth parameters of the invasive gastropod Melanoides tuberculata (Müller, 1774) (Gastropoda, Thiaridae) in a semi-arid region, Northeastern Brazil. Acta. Sci. Biol. Sci. 41: e45720. https://doi.org/10.4025/ actascibiolsci.v41i1.45720

OLIVEIRA, I.B., LAVANDER, H.D., LIMA, P.C.M., OLIVEIRA, C.Y.B., DANTAS, D.M.M. \& GÁLVEZ, A.O. (2019a). Effect of stocking density on the growth and survival of Anomalocardia brasiliana (Gmelin, 1791) (Bivalvia: Veneridae) post-larvae. Cienc. Rural 49(12): e20190420. http://dx.doi.org/10.1590/01038478cr20190420

OLIVEIRA, C.Y.B., OLIVEIRA, C.D., ALMEIDA, A.J., GÁLVEZ, A.O., \& DANTAS, D.M. (2019b). Phytoplankton responses to an extreme drought season: A case study at two reservoirs from a semiarid region, Northeastern Brazil. J. Limnol. 78(2): 176-184. https://doi.org/10.4081/jlimnol.2019.1869

OLIVEIRA, C.Y.B., LIMA, J., OLIVEIRA, C.D.L., LIMA, P.C., 
GÁLVEZ, A.O. \& DANTAS, D.M. (2020). Growth of Chlorella vulgaris using wastewater from Nile tilapia (Oreochromis niloticus) farming in a low-salinity biofloc system. Acta Sci. Technol. 42: e46232. https://doi.org/10.4025/actascitechnol. v42i1.46232

REICHWALDT, E.S. \& GHADOUANI, A. 2012. Effects of rainfall patterns on toxic cyanobacterial blooms in a changing climate: Between simplistic scenarios and complex dynamics. Water Res. 46(5): 1372-1393. https://doi.org/10.1016/j.watres.2011.11.052

RODRIGUES, A.M.L. 2009. Ecologia populacional do molusco bivalve Anomalocardia brasiliana (Gmelin, 1791) (Bivalvia, Veneridae) em praias da região estuarina do Rio Apodi/MossoróRN. Mossoró. 93f. (Master Thesis). Universidade Federal Rural do Semi-Árido). Disponível em: < http://livros01.livrosgratis. com.br/cp119533.pdf> Acesso em: 14 mar. 2018.

SAMOCHA, T. M., PRANGNELL, D.I., HANSON, T.R., TREECE, G.D., MORRIS, T.C., CASTRO, L.F. \& STARESINIC, N. 2017. Design and Operation of Super Intensive, Biofloc-Dominated Systems for Indoor Production of the Pacific White Shrimp, Litopenaeus vannamei - The Texas A\&M AgriLife Research Experience. The World Aquaculture Society, 368.

TECLU, D., TIVCHEV, G., LAING, M. \& WALLIS, M. 2009. Determination of the elemental composition of molasses and its suitability as carbon source for growth of sulphate-reducing bacteria. J. Hazard. Mater. 161(3): 1157-1165. https://doi. org/10.1016/j.jhazmat.2008.04.120

TROELL, M., JOYCE, A., CHOPIN, T., NEORI, A., BUSCHMANN,
A. \& FANG, J.G. 2009. Ecological engineering in aquaculture - potential for integrated multi-trophic aquaculture (IMTA) in marine offshore systems. Aquaculture 297: 1-9. https://doi. org/10.1016/j.aquaculture.2009.09.010

VAN WYK, P. 1999. Nutrition and feeding of Litopenaeus vannamei in intensive culture systems. In: Van Wyk, P.; Davis-Hodgkins, M.; Laramore, R.; Main, K.L.; Mountain, J.; Scarpa, J. 1999 Farming marine shrimp in recirculating freshwater systems. Florida Department of Agriculture and Consumer Services, Tallahassee. p. 125-140.

WEHR, J.D., SHEATH, R.G. \& KOCIOLEK, J.P. 2015. Freshwater algae of North America ecology and classification. $2^{\circ}$ ed. San Diego: Academic Press. 1066p.

WEI, Y., LIAO, S. \& WANG, A. 2016. The effect of different carbon sources on the nutritional composition, microbial community and structure of bioflocs. Aquaculture 465: 88-93. https://doi. org/10.1016/j.aquaculture.2016.08.040

YUSOFF, F.M., MATIAS-PERALTA, H. \& SHARIFF, M. 2010. Phytoplankton population patterns in marine shrimp culture ponds with different sources of water supply. Aquat. Ecosyst. Health Manag. 13(4): 458-464. https://doi.org/10.1080/146349 88.2010 .525163

VAN APELDOORN, M.E., VAN EGMOND, H.P., SPEIJERS, G.J.A. \& BAKKER, G.J.I. 2007. Toxins of cyanobacteria. Mol. Nutr. Food Res. 51: 7-60. https://doi.org/10.1002/ mnfr.200600185

ZAR, J. H. 1999. Biostatistical analysis. Pearson Education India. 